\title{
REACTIVATION OF VIRAL HEPATITIS B IN RENAL TRANSPLANT PATIENTS: A CASE REPORT
}

KEY WORDS:

\section{Rachid Abi}

\section{Hicham Elannaz*}

\section{Yassine Khayar}

\section{Yousra Elkhayat}

\section{Moahmed}

Bahadi

\section{Safae Elkochri}

\section{Mohammed} Reda Tagajdid

\section{Idriss Lahlou} Amine
Department Of Virology, Mohammed V Military Teaching Hospital, Morocco. MohammedV University, Morocco

Department Of Virology, Mohammed V Military Teaching Hospital, Morocco. MohammedV University, Morocco* Corresponding Author

Department Of Virology, Mohammed V Military Teaching Hospital, Morocco. MohammedV University, Morocco

Department Of Virology, Mohammed V Military Teaching Hospital, Morocco. MohammedV University, Morocco

Transplant Department, Mohammed V Military Teaching Hospital, Morocco. MohammedV University, Morocco

Department Of Virology, Mohammed V Military Teaching Hospital, Morocco. MohammedV University, Morocco

Department Of Virology, Medicine And Pharmacy, Sidi Mohamed Ben Abdallah University, Morocco

Department Of Virology, Mohammed V Military Teaching Hospital, Morocco. MohammedV University, Morocco

Hepatitis B virus (HBV) reactivation is defined as the increase in viremia (> 1 logl0 IU / ml) in a known patient with chronic or HBV-resolved infection. Since covalently closed circular deoxyribonucleic acid (cccDNA) is not removed from the hepatocytes, any event affecting the immune status promotes viral reactivation, sometimes severe or even fatal. We report an observation of an immunodeficient patient in whom viral B reactivation occurred one year after renal transplantation.

\section{INTRODUCTION}

hepatitis $\mathrm{B}$ virus (HBV) reactivation is defined as the increase in viremia (> 1 log $10 \mathrm{IU} / \mathrm{ml}$ ) in a known patient with chronic or HBV-resolved infection. Since covalently closed circular deoxyribonucleic acid (cccDNA) is not removed from the hepatocytes, any event affecting the immune status promotes viral reactivation, sometimes severe or even fatal.

Serological profiles combining significant titles of anti-HBs and anti-HBC antibodies have long been considered as serological scars indicating a former HBC viral hepatitis. However, the development of PCR techniques has revealed the persistence of the hepatitis B genome (HBV) which is a potential source of viral reactivation.

We report an observation of an immunodeficient patient in whom viral $B$ reactivation occurred one year after renal transplantation.

\section{CASE PRESENTATION}

male patient aged 65 , followed since 2005 for renal failure in the Nephrology department. In 2010; the patient had received a kidney transplant. A pre-transplant assessment revealed a level of anti HBs Antibody at $50 \mathrm{IU} / \mathrm{ml}$ associated with $\mathrm{HBC}$ Ab's defining post-contact immunization against HBV.

One year after the kidney transplant, during which the patient has received immunosuppressive treatment, the evolution was marked by the appearance of a hepatic cytolysis (ALAT:230UI/1). The markers of acute hepatitis $\mathrm{A}$ (anti-HAV $\operatorname{IgM}$ ), hepatitis $\mathrm{E}$ (anti-HEV IgM) and hepatitis $\mathrm{C}$ were negatives. Acute infection or reactivation of Herpesviridae (cytomegalovirus, Epstein-Barr virus, varicella zoster virus and Herpes simplex virus) has been eliminated. In contrast, the serology confirmed the diagnosis of active viral hepatitis $\mathrm{B}$ (positive HBs antigen and anti-HBc antibodies) with high viral replication confirmed by quantification of viral DNA using real-time PCR COBAS $₫$ Ampliprep / COBAS $₫$ TaqMan® HBV (8.45 log IU/ ml; $284,000,000 \mathrm{IU} / \mathrm{ml})$. The antigen and anti-hepatitis Delta antibody were negative. The diagnosis of reactivation of the hepatitis $B$ virus in relation to immunosuppression was retained, the patient was put under Entecavir. The evolution was marked by a rapid biological response with undetectable viral DNA.

\section{DISCUSSION}

HBV reactivation can be classified into two broad categories based on the initial serologic profile: reactivation of HBV in patients who are positive for hepatitis B surface antigen (HBsAg) in serum with or without the presence of HBV DNA. The reverse seroconversion is defined as the reappearance of viral DNA and HBsAg in individual's serum who were initially negative for both before immunosuppression.

The HBV reactivation may be variable depending on the status of the host, the underlying disease, and the type of immunosuppressive therapy (2). This can occur either early in the first 2 weeks after the beginning of chemotherapy or more than one year after the end of immunosuppressive therapy (2). Understanding the risk factors and the mechanisms That may induce the reactivation of HBV, helps certainly to understand and quantify the risk of $\mathrm{HBV}$ reactivation and its consequences (3).

\begin{tabular}{|c|c|c|}
\hline Submitted : $16^{\text {th }}$ August 2019 & Accepted : $17^{\text {th }}$ September 2019 & Publication : 15 $^{\text {th }}$ October, 2019 \\
\hline wwww.worldwidejournals.com & &
\end{tabular}


The grafted patient has multiple risk factors favoring the development of active hepatitis B: transfusion contamination, transmission by a chronic carrier donor of $\mathrm{HBV}$, or reactivation of a latent $B$ virus in an asymptomatic carrier or in a patient who is nevertheless immunized as in our observation (5).

It is therefore necessary to evaluate the infectious risk due to ciclosporin and corticosteroids that these patients receive after the transplant, which may decrease the immune reaction of the body. As in our observation, it is only at the time of the immune rebound at the end of the intense and prolonged immunosuppressive treatment, that the hepatitis has manifest itself, sometimes dramatically considering the large number of infected hepatocytes (5).

This immune revival can sometimes lead to the elimination of the virus, but in other cases, such as in our case, the selection pressure may favor the appearance of a mutated $B$ virus in the pre-C region $(1,5)$

These reactivations are potentially serious: risk of fulminant hepatitis, cirrhosis or even death, increased risk of venoocclusive disease or graft-versus-host disease, but the evolution is most often favorable with even cases of spontaneous elimination of the virus despite the immunosuppression context(6).

The management of HBV reactivation is centered on the likelihood of the risk of reactivation based on the risk factor profile of an individual patient (7). All patients who are either at high or moderate risk of HBV reactivation should be considered candidates for prophylactic anti-HBV therapy. Usually, we recommend starting anti-HBV therapy before starting immune-suppressive therapy and a baseline complete metabolic profile, complete blood count, prothrombin time, and serum HBV-DNA levels are recommended (8). It is important to evaluate if the patient has chronic hepatitis B and should be a candidate for treatment of CHB based on serum ALT level, AST level, albumin level, platelet count, and other laboratory parameters and physical examination (9). In endemic areas, if a patient presents with increased ALT level in the setting of immunosuppressive therapies, it is prudent to consider checking for serum HBV DNA. We also recommend routine monitoring with the earlierdescribed tests every 3 months while on anti-HBV therapy. Consideration of referral to either a hepatology or infectious disease specialist before cancer chemotherapy in those at risk of hepatitis $B$ reactivation is recommended (10).

\section{CONCLUSION}

prevention after transplantation in a patient with positive anti$\mathrm{HBs}$ and anti-HBC antibodies requires regular monitoring of the anti-HBs $\mathrm{Ab}$ title. In case of a significant decrease of this one, several approaches can be discussed: active immunization by vaccination (2-10), passive immunization by regular injection of specific anti-HBs immunoglobulins, or daily oral administration of antivirals capable of inhibiting the replication viral (2).

\section{REFERENCES}

1. François ROMAND $(1,4)$, Mauricette MICHALLET, Christian PICHOUD, Christian TREPO, Fabien ZOULIM. Réactivation virale $B$ après greffe de moelle allogénique chez un malade précédemment guéri d'une hépatite virale B. Gastroenterol Clin Biol, 1999,23,770-774.

2. Rohit Loombal and T. Jake Liang. Hepatitis B Reactivation Associated With Immune Suppressiveand Biological Modifier Therapies: Current Concepts,Management Strategies, and Future Directions. Gastroenterology 2017;152:1297-1309.

3. Mary Patricia Pauly, Lue-Yen Tucker, Jean-Luc Szpakowski, Joanna B. Ready,David Baer, Jessica Hwang, and Anna S.-F. Lok. Incidence of Hepatitis B Virus Reactivation andHepatotoxicity in Patients Receiving Long-term TreatmentWith Tumor Necrosis Factor Antagonists. Clinical Gastroenterology and Hepatology 2018;16:1964-1973.

4. A. Fylaktou, M. Daoudaki, V. Dimou, E. Sianou, D. Papaventsis, I. Mavrovouniotis, I. Fouzas, and V. Papanikolaou Hepatitis B Reactivation in a Renal Transplant Patient Due to a Surface Antigen Mutant Strain: A Case Report.Transplantation Proceedings, 44, 2773-2775 (2012).

5. Hepatitis B Virus Reactivation Guideline: Patient Summary. American
Gastroenterological Association. Gastroenterology 2015; 149:496-497.

6. ANN T. MA, JORDAN J. FELD. Hepatitis B Reactivation With Hepatitis C Treatment: Bringing Some Clarity to the Black Box. Gastroenterology, 201803-01, Volume 154,Numéro 4

7. Saab S, Dong MH, Joseph TA, et al. Hepatitis B prophylaxis in patients undergoing chemotherapy for lymphoma: a decision analysis model. Hepatology 2007;46:1049-1056.

8. Kohrt HE, Ouyang DL, Keeffe EB. Systematic review: lamivudine prophylaxis for chemotherapy-induced reactivation of chronic hepatitis B virus infection. Aliment Pharmacol Ther 2006;24:1003-1016.

9. Huang $\mathrm{H}, \mathrm{Li} X, \mathrm{Zhu}$ J, et al. Entecavir vs lamivudine for prevention of hepatitis B virus reactivation among patients with untreated diffuse large B-cell lymphoma receiving $\mathrm{R}-\mathrm{CHOP}$ chemotherapy: a randomized clinical trial. JAMA 2014;312:2521-2530.

10. Hilgendorf I, Loebermann $\mathrm{M}$, Borchert $\mathrm{K}$, et al. Tenofovir for treatment of hepatitis B virus reactivation in patients with chronic GVHD. Bone Marrow Transplant 2011;46:1274-1275. 